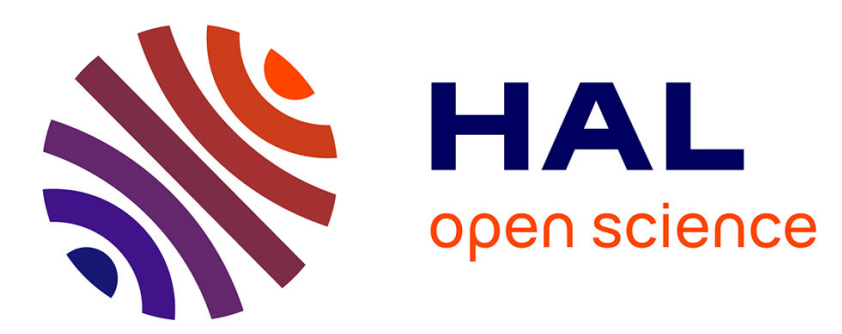

\title{
Physical and Structural Characterization of Biofield Treated Imidazole Derivatives
}

Mahendra Kumar Trivedi, Alice Branton, Dahryn Trivedi, Gopal Nayak, Gunin Saikia, Snehasis Jana

\section{To cite this version:}

Mahendra Kumar Trivedi, Alice Branton, Dahryn Trivedi, Gopal Nayak, Gunin Saikia, et al.. Physical and Structural Characterization of Biofield Treated Imidazole Derivatives. Natural Products Chemistry \& Research, 2018, 3 (5), pp.1000187. hal-01409590

\section{HAL Id: hal-01409590 \\ https://hal.science/hal-01409590}

Submitted on 6 Dec 2016

HAL is a multi-disciplinary open access archive for the deposit and dissemination of scientific research documents, whether they are published or not. The documents may come from teaching and research institutions in France or abroad, or from public or private research centers.
L'archive ouverte pluridisciplinaire HAL, est destinée au dépôt et à la diffusion de documents scientifiques de niveau recherche, publiés ou non, émanant des établissements d'enseignement et de recherche français ou étrangers, des laboratoires publics ou privés.

\section{(c)(1)}

Distributed under a Creative Commons Attribution| 4.0 International License 


\title{
Physical and Structural Characterization of Biofield Treated Imidazole Derivatives
}

\author{
Mahendra Kumar Trivedi ${ }^{1}$, Alice Branton ${ }^{1}$, Dahryn Trivedi ${ }^{1}$, Gopal Nayak ${ }^{1}$, Gunin Saikia ${ }^{2}$ and Snehasis Jana ${ }^{\star}$ \\ ${ }^{1}$ Trivedi Global Inc., 10624 S Eastern Avenue Suite A-969, Henderson, NV 89052, USA \\ ${ }^{2}$ Trivedi Science Research Laboratory Pvt. Ltd., Hall-A, Chinar Mega Mall, Chinar Fortune City, Hoshangabad Rd., Bhopal, Madhya Pradesh, India
}

\begin{abstract}
Imidazole derivatives have attracted significant interests in recent time for their usefulness in synthetic heterocyclic chemistry, analytical chemistry and pharmacology. Aim of present study was to evaluate the impact of biofield treatment on two imidazole derivatives (i.e., imidazole and 2-methylimidazole) by various analytical methods. The biofield treatment was done by Mr. Trivedi on both the compounds and both control and treated samples of imidazole and 2-methylimidazole were characterized with respect to physical, and structural properties using X-ray diffraction (XRD), differential scanning calorimetry (DSC), thermogravimetric analysis (TGA), Fourier transform infrared (FTIR), ultraviolet-visible (UV-Vis) spectroscopy, and Gas chromatography-Mass spectrometry (GC-MS). X-ray diffraction study revealed that crystallite size varied in a different way for imidazole and 2-methylimidazole due to the presence of methyl group in 2-c position although their core was same. Treated sample of imidazole showed a slight increase in crystallite size (6.5\%); however, treated 2-methylimidazole showed a significant increase $(166.68 \%)$ in crystallite size along with decrease in peak intensity as compared to control. The latent heat of fusion $(\Delta \mathrm{H})$ of imidazole was increased up to $0.62 \%$ in treated sample as compared to control; whereas in treated 2-methylimidazole, the $\Delta \mathrm{H}$ was decreased by $22 \%$ as compared to control. Maximum degradation temperature $\left(T_{\text {mar }}\right)$ from TGA of imidazole was remained same but 2-methylimidazole was increased by $1.5 \%$ as compared to control. FT-IR spectra showed slight change in stretching frequencies of treated imidazole and 2-methylimidazole as compared to control. Both the imidazole and 2-methylimidazole showed similar UV absorbance maxima as compared to respective control sample. GC-MS data revealed that isotopic abundance ratio of either ${ }^{13} \mathrm{C} /{ }^{12} \mathrm{C}$ or ${ }^{15} \mathrm{~N} /{ }^{14} \mathrm{~N}$ or ${ }^{2} \mathrm{H} /{ }^{1} \mathrm{H}(\mathrm{PM}+1 / \mathrm{PM})$ of treated imidazole was significantly increased up to $232.51 \%$ as compared to control, however, isotopic abundance ratio of ${ }^{13} \mathrm{C} /{ }^{12} \mathrm{C}$ or ${ }^{15} \mathrm{~N} /{ }^{14} \mathrm{~N}$ or ${ }^{2} \mathrm{H} /{ }^{1} \mathrm{H}$ (PM+1/PM) of treated 2-methylimidazole showed a minor change from -1.68 upto $1.68 \%$ as compared to control. Overall, the experimental results suggest that biofield treatment has significant effect on structural and thermal properties of imidazole and 2-methylimidazole.
\end{abstract}

Keywords: Imidazole; 2-methylimidazole; Biofield treatment; Fourier transform infrared; Differential scanning calorimetry; Thermogravimetric analysis; $\mathrm{X}$-ray diffraction

\section{Abbreviations}

XRD: X-ray diffraction; FT-IR: Fourier transform infrared; GCMS: Gas chromatography-Mass spectrometry; UV-Vis: Ultravioletvisible spectroscopy; DSC: Differential scanning calorimetry; TGA: Thermogravimetric analysis; PM: Primary molecule $(\mathrm{m} / \mathrm{z}=68$ for imidazole, $\mathrm{m} / \mathrm{z}=82$ for 2 -methyl imidazole); $\mathrm{PM}+1$ : isotopic molecule $(\mathrm{m} / \mathrm{z}=69$ for imidazole and $\mathrm{m} / \mathrm{z}=83$ for 2 -methylimidazole)

\section{Introduction}

Imidazole is a highly polar (dipole moment 3.61D) one of the fivemembered nitrogen containing heterocyclic ring, which is soluble in both organic and inorganic polar solvents. It is amphoteric in nature and aromatic in character due to the presence of $6 \pi$-electrons. The nitrogen attached with the hydrogen has a lone pair of electrons bringing the required $6 \pi$-electrons for aromaticity. The hydrogen atom can be located on either of the two nitrogen atoms due to resonance structures of imidazole [1]. Synthetic chemistry based on medicinal compounds concerned with the properties of the starting building blocks, their development and evaluation of biological activity. The biological activity of the compounds mainly depends upon the starting material and mechanism is well-studied at the molecular level [2]. The introduction of imidazole nucleus a conventional pharmacophore in medicinal compounds have made it versatile heterocyclic nucleus possessing wide range of biological activities. Imidazole, the core of naturally occurring nucleotides, is responsible for their numerous biological activities that allows them to interact easily with the biopolymers of the living system and functions [3]. Substituted imidazole have good antibacterial activity which revealed good inhibition against various tested microbial strains. Vijesh et al. reported that some of the imidazole derivatives (3-aryl-1H-imidazole4-carbaldehyde thiosemicarbazones) have excellent activity even better than standard drug, i.e., streptomycin against Pseudomonas aeruginosa and Clostridium perfringens [4]. Ucucu et al. had reported that synthetic 1-benzyl-2-substituted-4,5-diphenyl-1H-imidazole derivative worked well as analgesic on Swiss albino mice of both sexes. One of the derivative of imidazole has shown responses very close to morphine [5]. A newly synthesized compound, N-cyano substituted imidazole derivatives has shown fungicidal activities against Rhizoctonia solani, at a concentration of $50 \mu \mathrm{g} / \mathrm{mL}$. This compound has identified as the most potent candidate with an $\mathrm{EC}_{50}$ of $2.63 \mu \mathrm{g} / \mathrm{mL}$ against Rhizoctonia Solani [6]. Yang et al. has been reported that substitution of the imidazolyl-3-position with a naphthylacyl or bromophenacyl group, vital for modifying its cytotoxic activity [7].

The chemical or physical stability is the most anticipated quality of a molecule to be used in pharmaceutical purposes. In order to increase its shelf life and effectiveness there is a need to increase the stability of the compound both chemically as well as physically. The stability

*Corresponding author: Snehasis Jana, Trivedi Science Research Laboratory Pvt. Ltd., Hall-A, Chinar Mega Mall, Chinar Fortune City, Hoshangabad Rd. Bhopal- 462026, Madhya Pradesh, India, Tel: +91-755-6660006; E-mail: publication@trivedisrl.com

Received August 12, 2015; Accepted August 22, 2015; Published August 26, 2015

Citation: Trivedi MK, Branton A, Trivedi D, Nayak G, Saikia G, et al. (2015) Physical and Structural Characterization of Biofield Treated Imidazole Derivatives. Nat Prod Chem Res 3: 187. doi:10.4172/2329-6836.1000187

Copyright: $\odot 2015$ Trivedi MK, et al. This is an open-access article distributed unde the terms of the Creative Commons Attribution License, which permits unrestricted use, distribution, and reproduction in any medium, provided the original author and source are credited. 
could be enhanced by Mr. Trivedi's biofield treatment which is already known to alter the physical, and structural properties of various living and non-living substances [8]. The biofield is the electromagnetic field which surrounds the human body can be harnessed from the universe and have applied on materials by experts in a controlled way to make the changes $[9,10]$. This phenomenon is experimentally demonstrated by researchers using medical technologies such as electromyography, electrocardiography and electroencephalogram [9]. Mr. Trivedi has the ability to harness the energy from the universe and can transmit into any object, living or nonliving things [11]. Mr. Trivedi's unique biofield treatment is also known as The Trivedi Effect which has been applied in various research fields including microbiology [12], agriculture, $[13,14]$ and biotechnology [15]. The stability of the complexes with both imidazole derivatives taken for this study depends mostly on the substituent situated between the nitrogen atoms of the imidazole ring [16]. Imidazole containing organic materials have better solubility in common polar organic and inorganic solvents compared to other heterocyclic moieties [17]. So in this study, Mr. Trivedi's biofield treatment was applied to treat imidazole derivatives for evaluation of their physical, thermal and spectral properties as compared to control.

\section{Materials and Methods}

\section{Study design}

Imidazole and 2-methylimidazole were procured from Lobachemie Pvt. Ltd., India. Each compound was divided into two parts and coded as control and treatment. The control samples were remained as untreated and treatment samples were in sealed pack were handed over to Mr. Trivedi for biofield treatment in laboratory conditions. Mr. Trivedi provided this treatment through his energy transmission process to the treatment groups. The control and treated samples were evaluated using various spectroscopic, thermal and physical techniques.

\section{$\mathrm{X}$-ray diffraction (XRD) study}

XRD analysis was carried out on Phillips, Holland PW 1710 X-ray diffractometer system, with radiation of wavelength $1.54056 \AA$. The crystallite size $(\mathrm{G})$ was calculated by using formula:

\section{$\mathrm{G}=\mathrm{k} \lambda /(\mathrm{b} \operatorname{Cos} \theta)$}

Here, $\lambda$ is the wavelength of radiation, $b$ is full width half maximum (FWHM) of peaks and $\mathrm{k}$ is the equipment constant $(=0.94)$. The average value of $\mathrm{G}$ was taken for both control $(\mathrm{Gc})$ and treated $(\mathrm{Gt})$ samples to calculate $\%$ change in crystallite size.

\section{Percent change in crystallite size $=[(\mathrm{Gt}-\mathrm{Gc}) / \mathrm{Gc}] \times 100$}

\section{Differential scanning calorimetry (DSC) study}

DSC data were obtained by using Perkin Elmer/Pyris-1, USA at flow rate of $5 \mathrm{ml} / \mathrm{min}$ using closed aluminum pan. Melting temperature and latent heat of fusion were obtained from the DSC curve.

Percent change in latent heat of fusion was calculated using following equation

$\%$ change in Latent heat of fusion $=\frac{\left[\Delta \mathrm{H}_{\text {Treated }}-\Delta \mathrm{H}_{\text {Control }}\right]}{\Delta \mathrm{H}_{\text {Control }}} \times 100$

Where, $\Delta \mathrm{H}_{\text {Control }}$ and $\Delta \mathrm{H}_{\text {Treated }}$ are the latent heat of fusion of control and treated samples, respectively.

\section{Thermogravimetric analysis (TGA)/ derivative thermogra- vimetry (DTG)}

TGA/DTG results were obtained by using Mettler Toledo simultaneous thermogravimetric analyzer at a heating rate of $5^{\circ} \mathrm{C} / \mathrm{min}$ from room temperature to $400^{\circ} \mathrm{C}$ under air atmosphere (sample mass 5-10 mg on aluminium pan).

Percent change in temperature at which maximum weight loss occur in sample was calculated using following equation:

$$
\% \text { change in } \mathrm{T}_{\max }=\left[\left(\mathrm{T}_{\text {max, treated }}-\mathrm{T}_{\max , \text { control }}\right) / \mathrm{T}_{\max , \text { control }}\right] \times 100
$$

Where, $\mathrm{T}_{\text {max, control }}$ and $\mathrm{T}_{\text {max, treated }}$ are temperature at which maximum weight loss occurs in control and treated sample, respectively.

\section{FT-IR spectroscopic characterization}

FT-IR spectra were acquired on Shimadzu's Fourier transform infrared spectrometer (Japan) with frequency range of 500-4000 $\mathrm{cm}^{-1}$. The imidazole derivatives were run as pressed disks using $\mathrm{KBr}$ as the diluent.

\section{UV-Vis spectroscopic analysis}

Photophysical properties were studied by Shimadzu UV-2400 PC series spectrophotometer with $1 \mathrm{~cm}$ quartz cell and a slit width of 2.0 $\mathrm{nm}$, wavelength was in the range of $200-400 \mathrm{~nm}$.

\section{GC-MS analysis}

The Gas chromatography-Mass spectrometry (GC-MS) analysis was performed on Perkin Elmer/auto system XL with Turbo Mass, USA, having detection limit up to 1 picogram. For GC-MS analysis the treated samples were further divided into four parts as T1, T2, T3 and T4. The GC-MS data was obtained in the form of $\%$ abundance vs. mass to charge ratio $(\mathrm{m} / \mathrm{z})$, which is known as mass spectrum. The isotopic ratio of $\mathrm{PM}+1 / \mathrm{PM}$ was expressed by its deviation in treated samples as compared to the control. The collective effect of the isotopic abundance ratio of $(\mathrm{PM}+1 / \mathrm{PM})$ of treated samples were calculated from the following formula:

Percent change in isotopic abundance

$$
=\frac{\mathrm{R}_{\text {Treated }}-\mathrm{R}_{\text {control }}}{\mathrm{R}_{\text {control }}} \times 100
$$

Where, $\mathrm{R}_{\text {Treated }}$ and $\mathrm{R}_{\text {Control }}$ are the ratio of intensity of masses from the mass spectrometry for treated and control samples respectively.

\section{Results and Discussion}

\section{$\mathrm{X}$-ray diffraction studies}

X-ray diffraction study was conducted on both control and treated samples of imidazole derivatives and their diffractograms are shown in Figure 1. As both the imidazole and 2-methyl imidazole (control and treated) were crystalline in nature so they exhibited very sharp and intense peaks (6000-30000 a.u.) in their respective X-ray diffractograms. The X-ray diffractogram of control imidazole showed peaks at $2 \theta$ equals to $12.89^{\circ}, 19.14^{\circ}, 20.31^{\circ}, 20.74^{\circ} 25.66^{\circ}, 25.91^{\circ}$ and $30.73^{\circ}$ whereas the X-ray diffractogram of treated imidazole showed peaks at $2 \theta$ equals to $13.01^{\circ}, 20.31^{\circ}, 20.93^{\circ}, 26.08^{\circ}, 30.74^{\circ}$, and $30.87^{\circ}$. In control sample of 2-methylimidazole, the X-ray diffractogram showed peaks at $2 \theta$ equals to $17.49^{\circ}, 17.76^{\circ}, 21.77^{\circ}, 25.87^{\circ}$ and $26.17^{\circ}$ where the treated 2-methylimidazole showed peaks at $2 \theta$ equals to $17.34^{\circ}, 17.59^{\circ}, 17.80^{\circ}$, $21.19^{\circ}, 25.88^{\circ}$ and $26.16^{\circ}$. XRD studies showed that crystal structure of imidazole was monoclinic and orthorhombic structure was found for 2-methylimidazole, which were well supported by reported literature data [18]. 

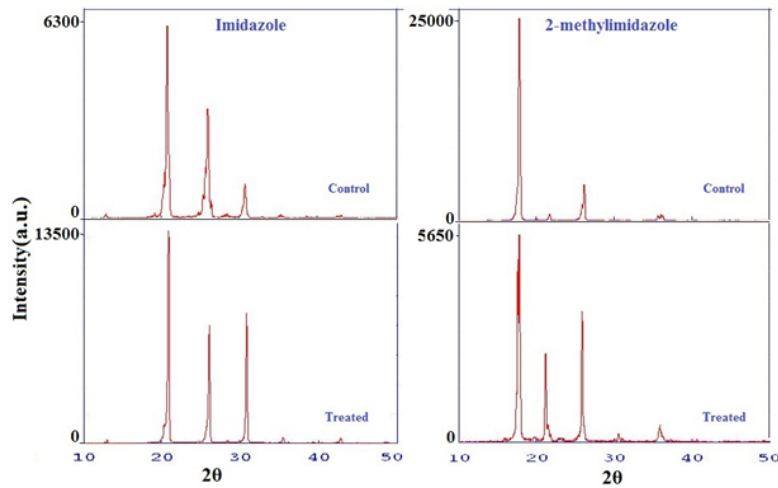

Figure 1: XRD diffractogram of control and treated samples of imidazole and 2-methylimidazole.

In case of imidazole crystallite size was increased to $6.5 \%$, however for 2-methylimidazole, crystallite size increased significantly up to $166.68 \%$ (Table 1). It is presumed that biofield energy may be absorbed by the treated imidazole molecules which may lead to the formation of crystalline long range pattern attributed to the high intensity of the XRD peaks. It was reported in previous literature that thermal annealing increase the crystallite size and thereby increase the intensity of the peaks $[19,20]$. After biofield treatment imidazole derivatives may absorbed high energy which enhances the crystallite size of the treated imidazole. The volume of unit cell of treated 2-methylimidazole was increased from $485.83 \times 10^{-24} \mathrm{~cm}^{3}$ to $497.32 \times 10^{-24} \mathrm{~cm}^{3}$ as $2.37 \%$ compared to control.

\section{DSC analysis}

The DSC analysis results of control and treated samples of imidazole and its derivative are presented in Table 2. The latent heat of fusion $(\Delta \mathrm{H})$, was increased for imidazole molecule from 158.8 to $159.5 \mathrm{~J} / \mathrm{g}$ whereas, $\Delta \mathrm{H}$ decreased from $137.2 \mathrm{~J} / \mathrm{g}$ (control) to 106 $\mathrm{J} / \mathrm{g}$ (treated) for 2-methylimidazole. There may be biofield energy favoring a strong ' $\mathrm{C}-\mathrm{H} \cdots \mathrm{N}$ ' H-binding interaction of methyl hydrogen in 2-methylimidazole. Higher melting point of 2-methylimidazole compared to imidazole was attributed to stronger H-bonding interactions via methyl ' $\mathrm{H}$ ' atoms and ring ' $\mathrm{N}$ ' atoms [21]. This result cannot be seen in imidazole as the 'methyl- $\mathrm{H}$ ' portion is absent in this molecule. As a result, treated 2-methyl imidazole sample needed less energy in the form of $\Delta \mathrm{H}$ to undergo the process of melting. However, imidazole does not have methyl group and any changes in $\Delta \mathrm{H}$ have not seen of melting for control and treated samples. The DSC result of treated imidazole $\left(90.19^{\circ} \mathrm{C}\right)$ did not show significant change in melting temperature as compared to control $89.86^{\circ} \mathrm{C}$. However, melting point of 2-methylimidazole was increased $147^{\circ} \mathrm{C}$ as compared to control $\left(145^{\circ} \mathrm{C}\right)$, i.e., change in $1.4 \%$ [22]. It is hypothised that biofield energy may be absorbed by 2-methylimidazole molecule which possibly lowered the torsional strain exerted by the methyl-H atoms.

\section{TGA/DTG analysis}

TGA thermogram (Figure 2a) showed that treated imidazole compound was less thermally stable than control sample. The onset degradation temperature for imidazole was at $170^{\circ} \mathrm{C}$ for control but $160^{\circ} \mathrm{C}$ for treated sample. The end-set degradation temperature was observed at $250^{\circ} \mathrm{C}$ for control and $235^{\circ} \mathrm{C}$ for treated sample, respectively. The decrease in thermal stability of imidazole to $6 \%$ may have increased the reactivity which may contribute to the lesser reaction time and temperature in production of imidazole derivatives.
But in case of 2-methylimidazole control sample (Figure $2 \mathrm{~b}$ ) started degrading around $140^{\circ} \mathrm{C}$ (onset) and stopped at $245^{\circ} \mathrm{C}$ (end-set). Besids this, treated 2-methylimidazole showed onset degradation temperature at $\sim 152^{\circ} \mathrm{C}$ and end-set around $240^{\circ} \mathrm{C}$. It indicated that onset temperature of treated 2-methylimidazole was increased by $8 \%$ as compared to control (Figure 2b). Furthermore, in this process, control 2-methylimidazole sample lost $\sim 97 \%$ and treated sample lost $74 \%$ of its weight. DTG thermogram showed $\mathrm{T}_{\max } \sim 192^{\circ} \mathrm{C}$ in control, whereas, it was increased to $\sim 195^{\circ} \mathrm{C}$ in treated 2 -methylimidazole. Thermal stability of 2-methylimidazole from $\mathrm{T}_{\max }$ was increased by $1.5 \%$ as compared to control. The increase in onset temperature, $\mathrm{T}_{\max }$, and endset temperature of the treated samples of 2-methylimidazole can be related to increase in thermal stability of treated molecule. The overall increases in thermal stability of treated 2-methylimidazole might be advantageous to be used as core moiety (pharmacophore) in medicine and synthetic biopolymers.

\section{UV-Vis spectroscopy}

UV spectra of control and biofield treated imidazole and 2-methyl imidazole are shown in Figure 3. Imidazole derivatives absorb UV light due to the presence of conjugated pi $(\pi)$ bonding systems $(\pi-\pi$ transition) and nonbonding electron system ( $\mathrm{n}-\pi^{*}$ transition). There are certain energy gaps between $\pi-\pi^{*}$ and $n-\pi^{*}$ orbitals. From the above experiments, it was observed that negligible structural changes occurred in treated samples as compared to control, which was not sufficiently large to alter UV-Visible spectral properties in solution state. Treated sample of imidazole (Figure 3 ) exhibited hypsochromic effect ( $1 \mathrm{~nm}$ change) in absorbance maxima $\left(\lambda_{\max }\right)$ at $207 \mathrm{~nm}$ compared to control at $208 \mathrm{~nm}$. Whereas, treated 2-methylimidazole exhibited bathochromic shift at the absorbance maxima $\left(\lambda_{\max }\right) 206 \mathrm{~nm}$ compared to $205 \mathrm{~nm}$ for control.

\section{FT-IR spectroscopic analysis}

FTIR spectra of control and treated samples of imidazole and 2-methylimidazole are presented in (Figures $4 \mathrm{a}$ and $4 \mathrm{~b}$ ) respectively. Secondary amine N-H stretching frequency was observed at $3018 \mathrm{~cm}^{-1}$ for control and $3020 \mathrm{~cm}^{-1}$ for treated sample of imidazole. IR spectra of both control and treated imidazole sample showed C-N stretching at $1448 \mathrm{~cm}^{-1}$ and out of plane $\mathrm{NH}_{2}$ bending at $659 \mathrm{~cm}^{-1}$. In case of 2-methylimidazole $\mathrm{N}-\mathrm{H}$ stretching was seen at $3020 \mathrm{~cm}^{-1}$ (control) and $3018 \mathrm{~cm}^{-1}$ (treated). These data indicated that there was slight changes in the hydrogen bonding environment in both treated and control samples of both imidazole and 2-methylimidazole. The broad absorption peaks were observed in the wavenumber ranges from 3400$2600 \mathrm{~cm}^{-1}$ for both control and treated samples assigned to bonding vibration of water molecules due to moisture absorption by samples [23]. In the FT-IR spectrum of imidazole showed a minor changes in the C-H stretching at $2791 \mathrm{~cm}^{-1}$ for control and $2794 \mathrm{~cm}^{-1}$ for treated one. Whereas in case of 2-methylimidazole $\mathrm{C}-\mathrm{H}$ stretching frequency was observed at $2681 \mathrm{~cm}^{-1}$ for control and $2690 \mathrm{~cm}^{-1}$ for treated sample. The N-H bending for imidazole was observed at $1541 \mathrm{~cm}^{-1}$ for both control and treated samples, while in case of 2-methyl imidazole $\mathrm{N}-\mathrm{H}$ bending was observed at $1595 \mathrm{~cm}^{-1}$ for both control and treated. The $\mathrm{C}-\mathrm{H}$ deformation bends were assigned to the peaks at $1301 \mathrm{~cm}^{-1}$ in and treated sample of 2-methylimidazole. The FT-IR results showed little changes in other vibrational frequencies for the $\mathrm{N}-\mathrm{H}$ and $\mathrm{C}-\mathrm{H}$ stretching frequencies, as well as bending vibration energies, which lead to the changes in packing parameters of imidazole crystal after biofield treatment validating the DSC and XRD results incorporated here. 
Citation: Trivedi MK, Branton A, Trivedi D, Nayak G, Saikia G, et al. (2015) Physical and Structural Characterization of Biofield Treated Imidazole Derivatives. Nat Prod Chem Res 3: 187. doi:10.4172/2329-6836.1000187

Page 4 of 8

\begin{tabular}{|c|c|c|c|}
\hline \multicolumn{2}{|c|}{ Organic compound } & \multirow{2}{*}{$\begin{array}{l}\text { Imidazole } \\
\text { Monoclinic }\end{array}$} & \multirow{2}{*}{$\begin{array}{c}\text { 2-Methyl Imidazole } \\
\text { Orthorhombic }\end{array}$} \\
\hline Crystal Structure & Group & & \\
\hline \multirow[t]{2}{*}{ Volume of unit cell } & Control & - & 485.83 \\
\hline & Treatment & - & 497.32 \\
\hline$\%$ Change in volume of unit cell & Treatment & - & 2.37 \\
\hline \multirow[t]{2}{*}{ Crystallite size } & Control & 85.83 & 52.33 \\
\hline & Treatment & 91.39 & 139.56 \\
\hline$\%$ change in 'G' & Treatment & 6.5 & 166.68 \\
\hline
\end{tabular}

Table 1: XRD analysis of control and treated samples of imidazole and 2-methylimidazole. -: Not reported.

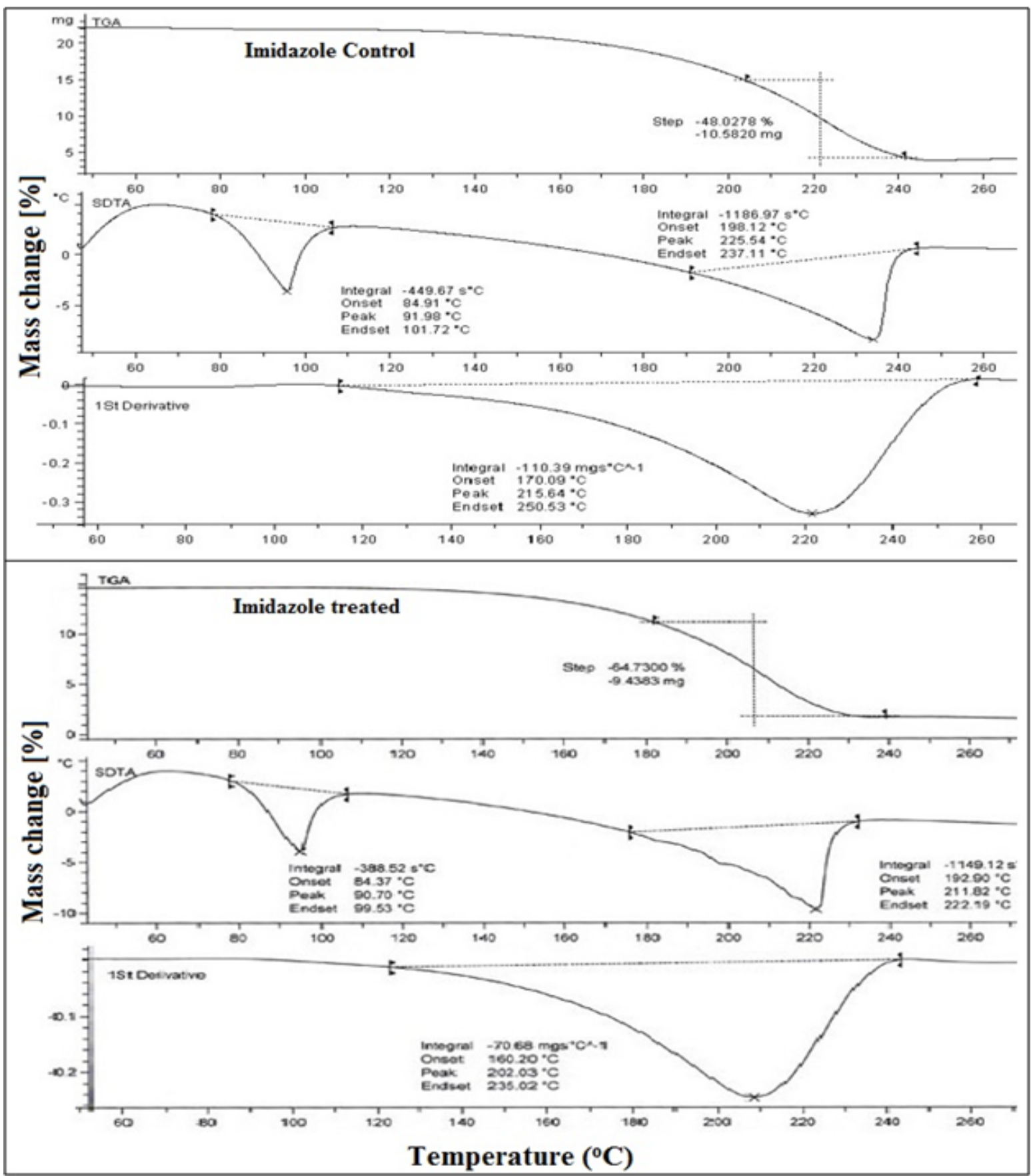

Figure 2 (a): TGA thermogram of control and treated imidazole. 


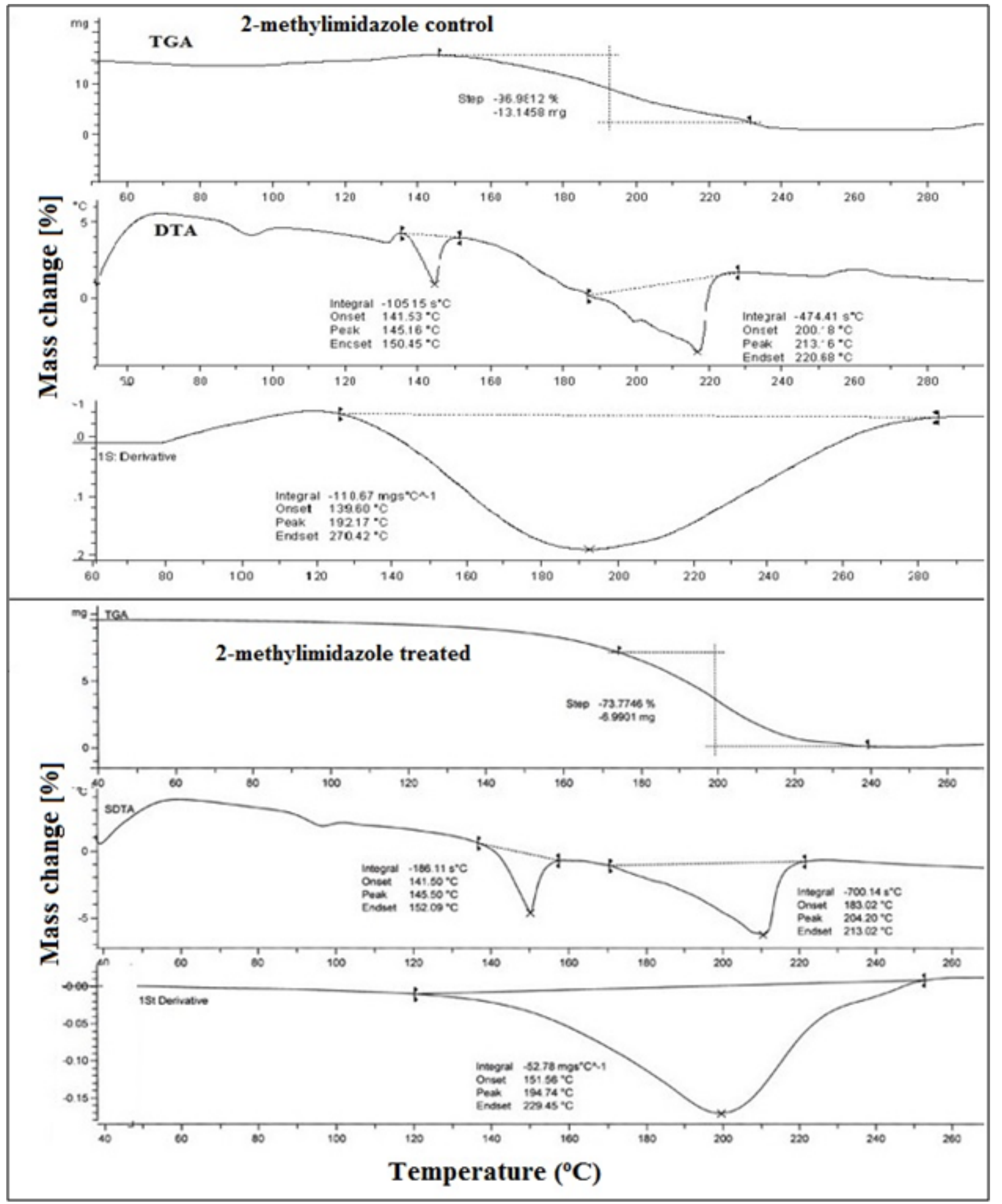

Figure 2 (b): TGA thermogram of control and treated 2-methylimidazole. 
Citation: Trivedi MK, Branton A, Trivedi D, Nayak G, Saikia G, et al. (2015) Physical and Structural Characterization of Biofield Treated Imidazole Derivatives. Nat Prod Chem Res 3: 187. doi:10.4172/2329-6836.1000187

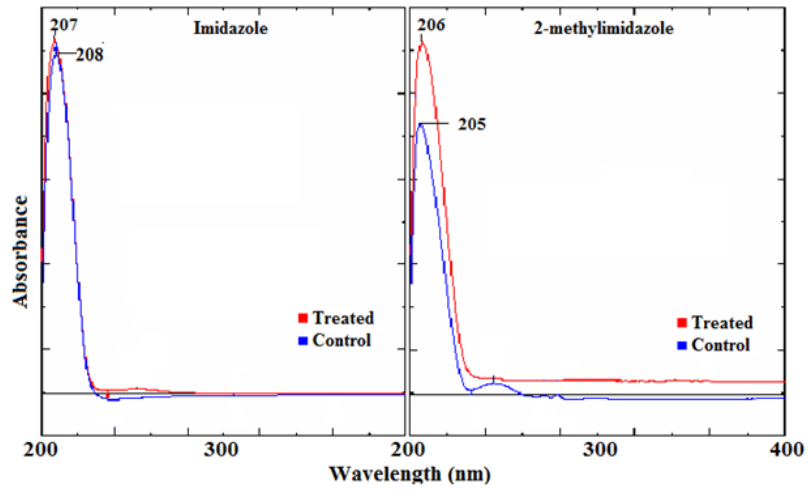

Figure 3: UV spectra of control and treated samples of imidazole and 2-methylimidazole.

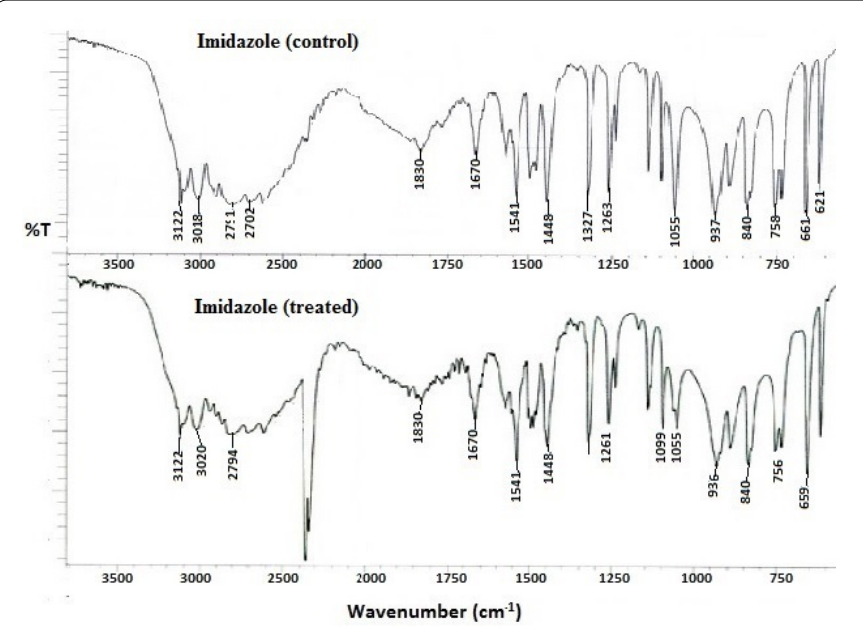

Figure 4 (a): FT-IR spectra of control and treated samples of imidazole.

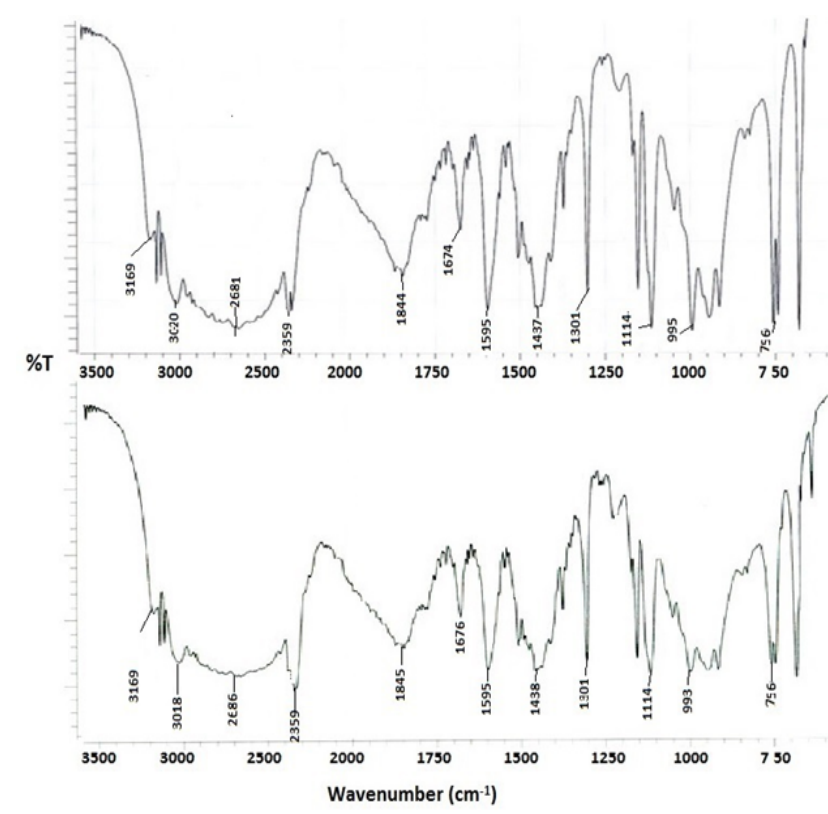

Figure 4 (b): FT-IR spectra of control and treated samples of 2-methylimidazole.

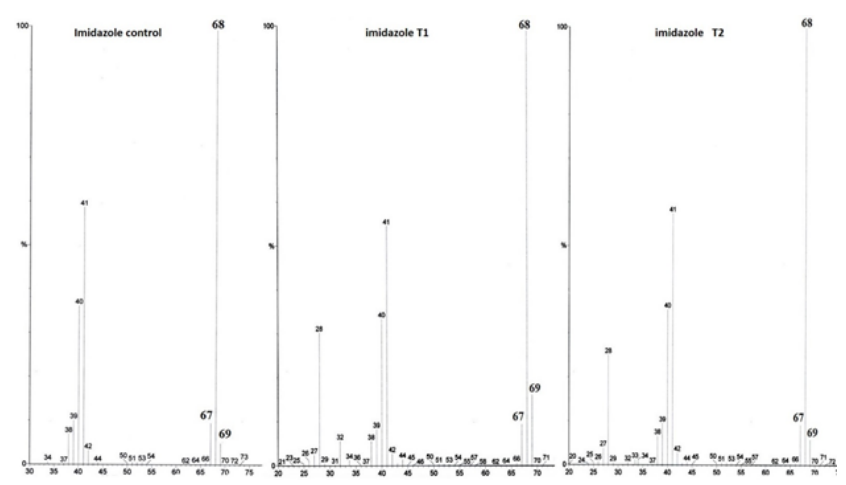

Figure 5 (a): GC-MS spectra of control and treated (T1 and T2) samples of imidazole.

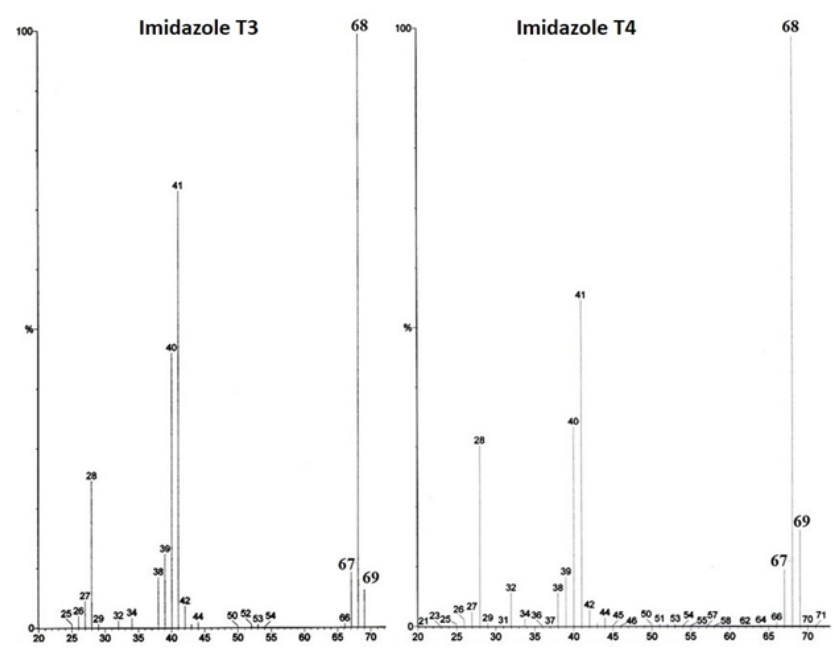

Figure 5 (b): GC-MS spectra of treated (T3 and T4) samples of imidazole.

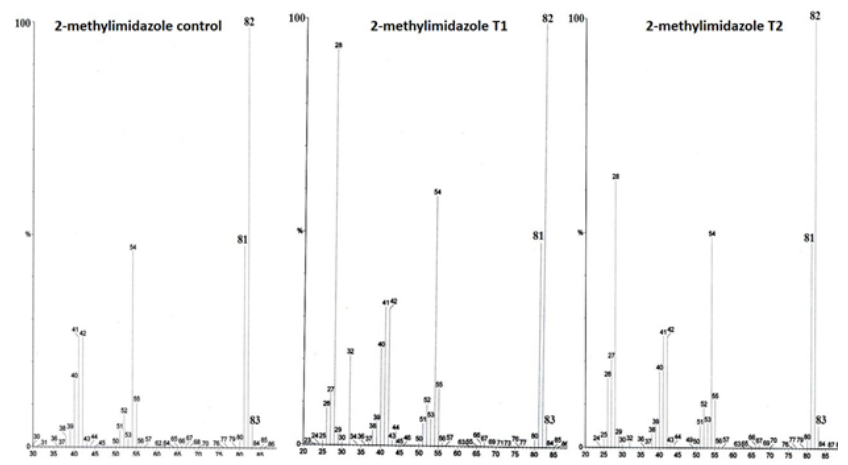

Figure 5 (c): GC-MS spectra of control and treated (T1 and T2) samples of 2-methylimidazole.

\section{GC-MS spectrometry}

The mass spectrum of control and treated samples of imidazole and 2-methylimidazole are shown in Figures 5a-5d. Treated samples were divided into four parts (T1, T2, T3 and T4) and analyzed at different times. Isotopic abundance ratio of ${ }^{13} \mathrm{C} /{ }^{12} \mathrm{C}$ or ${ }^{15} \mathrm{~N} /{ }^{14} \mathrm{~N}$ or ${ }^{2} \mathrm{H} /{ }^{1} \mathrm{H}(\mathrm{PM}+1 /$ $\mathrm{PM}$ ) in imidazole, determined using equation (1) is shown in Table 3. 
Citation: Trivedi MK, Branton A, Trivedi D, Nayak G, Saikia G, et al. (2015) Physical and Structural Characterization of Biofield Treated Imidazole Derivatives. Nat Prod Chem Res 3: 187. doi:10.4172/2329-6836.1000187

Page 7 of 8

\begin{tabular}{|c|c|c|c|}
\hline Parameter & & Imidazole \\
\hline \multirow{2}{*}{ Latent heat of fusion $\Delta \mathrm{H}(\mathrm{J} / \mathrm{g})$} & Control & 158.8 \\
\hline & Treatment & 159.5 \\
\cline { 2 - 4 } & Control & 89.8 & 137.2 \\
\hline
\end{tabular}

Table 2: DSC analysis of control and treated samples of imidazole and 2-methylimidazole.

\begin{tabular}{|c|c|c|c|c|}
\hline $\begin{array}{c}\text { Molecular } \\
\text { formulae/name }\end{array}$ & Molecular mass & & $\begin{array}{l}\text { Ratio of peak intensity } \\
\text { Observed (PM+1/PM) }\end{array}$ & $\%$ Change in (PM+1/PM) (Between control and treated) \\
\hline \multirow{5}{*}{$\underset{\text { Imidazole }}{\mathrm{C}_{3} \mathrm{H}_{4} \mathrm{~N}_{2}}$} & \multirow[t]{5}{*}{68} & Control & 4.86 & - \\
\hline & & $\mathrm{T} 1$ & 4.82 & -0.82 \\
\hline & & T2 & 5.73 & 17.90 \\
\hline & & T3 & 6.23 & 28.19 \\
\hline & & T4 & 16.16 & 232.51 \\
\hline \multirow{5}{*}{$\begin{array}{c}\mathrm{C}_{4} \mathrm{H}_{6} \mathrm{~N}_{2} \\
\text { 2-methyl } \\
\text { imidazole }\end{array}$} & \multirow[t]{5}{*}{82} & Control & 5.37 & \\
\hline & & T1 & 5.28 & -1.68 \\
\hline & & T2 & 5.20 & -3.17 \\
\hline & & T3 & 5.45 & 1.49 \\
\hline & & T4 & 5.46 & 1.68 \\
\hline
\end{tabular}

Table 3: Analysis of isotopic abundance of imidazole and 2-methylimidazole using gas chromatography mass-spectrometry (GC-MS). PM: primary molecule (m/z=68 for imidazole, $\mathrm{m} / \mathrm{z}=82$ for 2-methyl imidazole); $\mathrm{PM}+1$ : isotopic molecule ( $\mathrm{m} / \mathrm{z}=69$ for imidazole and $\mathrm{m} / \mathrm{z}=83$ for 2 -methylimidazole).

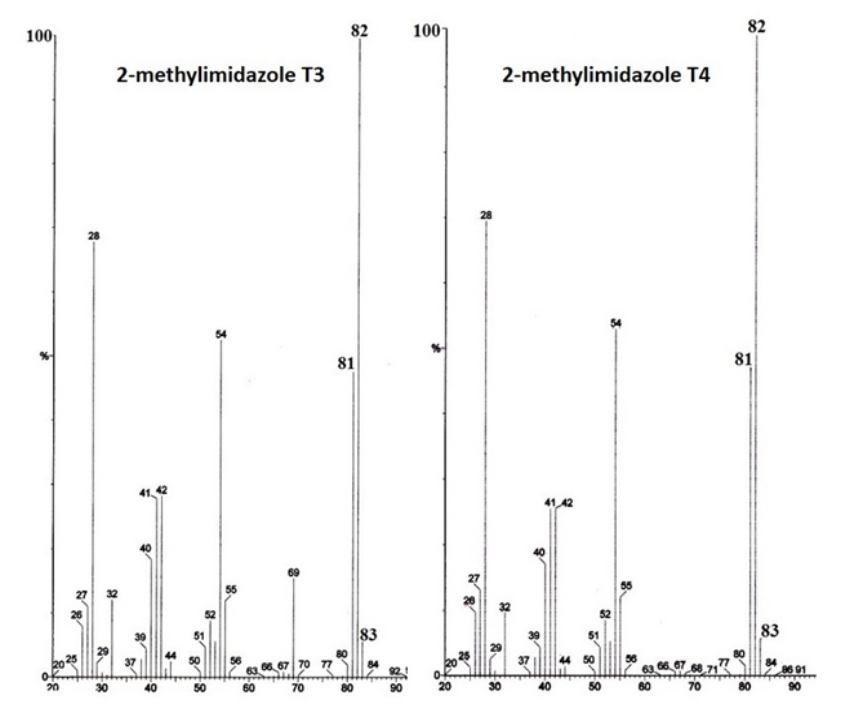

Figure 5 (d): GC-MS spectra of treated (T3 and T4) samples of 2-methylimidazole.

It showed that the isotopic ratio of ${ }^{13} \mathrm{C} /{ }^{12} \mathrm{C}$ or ${ }^{15} \mathrm{~N} /{ }^{14} \mathrm{~N}$ or ${ }^{2} \mathrm{H} /{ }^{1} \mathrm{H}(\mathrm{PM}+1 /$ $\mathrm{PM})$ in imidazole was significantly increased by $232.51 \%$ in sample $\mathrm{T} 4$, while it was increased by only $1.68 \%$ in treated (T4) 2 -methylimidazole as compared to control. The biofield treatment may have altered the natural abundance ratio of ${ }^{13} \mathrm{C} /{ }^{12} \mathrm{C}$ or ${ }^{15} \mathrm{~N} /{ }^{14} \mathrm{~N}$ or ${ }^{2} \mathrm{H} /{ }^{1} \mathrm{H}(\mathrm{PM}+1 / \mathrm{PM})$ of T4-imidazole from the control samples. Furthermore, it is assumed that imidazole molecule with higher isotopic ratio of ${ }^{13} \mathrm{C} /{ }^{12} \mathrm{C}$ or ${ }^{15} \mathrm{~N} /{ }^{14} \mathrm{~N}$ or ${ }^{2} \mathrm{H} /{ }^{1} \mathrm{H}(\mathrm{PM}+1 / \mathrm{PM})$, (T4), might have higher stability due to the increased $\mu$ (reduced mass) and binding energy in molecules with heavier isotopes. The heavier isotopes may form one of the following bonds like ${ }^{13} \mathrm{C}-{ }^{12} \mathrm{C},{ }^{13} \mathrm{C}-{ }^{13} \mathrm{C},{ }^{13} \mathrm{C}-{ }^{14} \mathrm{~N},{ }^{12} \mathrm{C}-{ }^{15} \mathrm{~N},{ }^{13} \mathrm{C}-{ }^{2} \mathrm{H},{ }^{15} \mathrm{~N}-{ }^{2} \mathrm{H}$, and ${ }^{13} \mathrm{C}-\mathrm{H}$ as compared to control. [24]. This higher binding energy may lead to increase the heat of reaction for imidazole $\mathrm{T} 4$ and reverse might happen in treated T1. Thus, GC-MS data suggested that biofield treatment has significantly altered the isotopic ratio of ${ }^{13} \mathrm{C} /{ }^{12} \mathrm{C}$ or ${ }^{15} \mathrm{~N} /{ }^{14} \mathrm{~N}$ or ${ }^{2} \mathrm{H} /{ }^{1} \mathrm{H}$ $(\mathrm{PM}+1 / \mathrm{PM})$ to $232.51 \%$, in treated imidazole molecule whereas isotopic ratio of $\mathrm{PM}+1 / \mathrm{PM}$ has remained same in treated 2-methylimidazole as compared to control.

\section{Conclusion}

In summary, the biofield treatment offers a remarkable means to alter the properties of imidazole and 2-methylimidazole at molecular level. Due to biofield treatment on 2-methylimidazole, crystallite size was significantly increased up to $166.68 \%$ by means of increasing the volume of unit cell in a crystal but imidazole has very small change in crystallite size up to $6.5 \%$ in XRD study. GC-MS data revealed that isotopic abundance ratio of ${ }^{13} \mathrm{C} /{ }^{12} \mathrm{C}$ or ${ }^{15} \mathrm{~N} /{ }^{14} \mathrm{~N}$ or ${ }^{2} \mathrm{H} /{ }^{1} \mathrm{H}(\mathrm{PM}+1 / \mathrm{PM})$ of treated imidazole was significantly changed $232.51 \%$ of $\mathrm{T} 4$ sample as compared to control, however, treated 2-methylimidazole showed a minor change (1.68\%) as compared to control. It is assumed that the enhancement in thermal stability of 2-methylimidazole could be more useful as a building block in various pharmaceutical products and biopolymers of pharmaceutical importance, which ultimately affect the shelf-life and efficacy of drug. Moreover, the treated imidazole found to be thermally less stable compared to control may be useful as reaction intermediate for various chemical reactions or it can be converted to 2-substituted imidazole for better stability. Furthermore, due to high isotopic abundance ratio of ${ }^{13} \mathrm{C} /{ }^{12} \mathrm{C}$ or ${ }^{15} \mathrm{~N} /{ }^{14} \mathrm{~N}$ or ${ }^{2} \mathrm{H} /{ }^{1} \mathrm{H}(\mathrm{PM}+1 / \mathrm{PM})$ of treated (T4) imidazole, bond might have highly stable with higher binding energy may lead to higher chemical stability than the control.

\section{Acknowledgement}

The authors would like to acknowledge the whole team of MGV Pharmacy College, Nashik for providing the instrumental facility. We would also like to thank Trivedi Science ${ }^{\mathrm{TM}}$, Trivedi Master Wellness ${ }^{\mathrm{TM}}$ and Trivedi Testimonials for their support during the work.

\section{References}

1. Verma A, Joshi S, Singh D (2013) Imidazole: Having versatile biological activities. J Chem 2013: 1-12.

2. Singhand H, Kapoor VK (2008) Medicinal and pharmaceutical chemistry (2nd edn). Vallabh Prakashan, New Delhi.

3. Starcevic K, Kralj M, Ester K, Sabol I, Grce M, et al. (2007) Synthesis, antiviral and antitumor activity of 2-substituted-5-amidino-benzimidazoles. Bioorg Med Chem 15: 4419-4426.

4. Vijesh AM, Isloor AM, Telkar S, Peethambar SK, Rai S, et al. (2011) Synthesis, characterization and antimicrobial studies of some new pyrazole incorporated imidazole derivatives. Eur J Med Chem 46: 3531-3536. 
Citation: Trivedi MK, Branton A, Trivedi D, Nayak G, Saikia G, et al. (2015) Physical and Structural Characterization of Biofield Treated Imidazole Derivatives. Nat Prod Chem Res 3: 187. doi:10.4172/2329-6836.1000187

5. Ucucu U, Karaburun NG, Isikdag I (2001) Synthesis and analgesic activity of some 1-benzyl-2-substituted-4,5-diphenyl-1H-imidazole derivatives. Farmaco 56: $285-290$

6. Yang WC, Li J, Chen Q, Yang GF (2012) Novel synthetic methods for N-cyano$1 \mathrm{H}$-imidazole-4-carboxamides and their fungicidal activity. Bioorg Med Chem Lett 22: 1455-1458.

7. Yang W, Wan X, Deng (2012) Design, synthesis and cytotoxic activities of novel hybrid compounds between 2-phenylbenzofuran and imidazole. Bioorg Med Chem Lett 22: 2726-2729.

8. Trivedi MK, Patil S, Shettigar H, Bairwa K, Jana S (2015) Phenotypic and biotypic characterization of Klebsiella oxytoca: An impact of biofield treatment. J Microb Biochem Technol 7: 203-206.

9. Rivera-Ruiz M, Cajavilca C, Varon J (2008) Einthoven's string galvanometer: The first electrocardiograph. Tex Heart Inst J 35: 174-178.

10. Rubik B (2002) The biofield hypothesis: Its biophysical basis and role in medicine. J Altern Complement Med 8: 703-717.

11. Trivedi MK, Patil S, Tallapragada RMR (2015) Effect of biofield treatment on the physical and thermal characteristics of aluminium powders. Ind Eng Manage 4: 151.

12. Trivedi MK, Patil S, Shettigar H, Gangwar M, Jana S (2015) Antimicrobial sensitivity pattern of Pseudomonas fluorescens after biofield treatment. J Infect Dis Ther 3: 222.

13. Sances F, Flora E, Patil S, Spence A, Shinde V (2013) Impact of biofield treatment on ginseng and organic blueberry yield. Agrivita J Agric Sci 35.

14. Lenssen AW (2013) Biofield and fungicide seed treatment influences on soybean productivity, seed quality and weed community. Agricultural Journal 8: $138-143$.
15. Patil SA, Nayak GB, Barve SS, Tembe RP, Khan RR (2012) Impact of biofield treatment on growth and anatomical characteristics of Pogostemon cablin (Benth.). Biotechnology 11: 154-162.

16. Barszcz B, Kulig J, Jezierska J, Lisowski J (1999) The role of the side group in reactions involving 1-propyl-2-methylimidazole and 1-propyl-2-imidazolecarboxaldehyde and $\mathrm{Co}(\mathrm{II}), \mathrm{Ni}(\mathrm{II}), \mathrm{Cu}(\mathrm{II})$ and $\mathrm{Zn}(\mathrm{II})$ ions. Pol J Chem 73: 447 456.

17. Zhao L, Sheng BL, Gui AW, Peng B, Wei H (2006) Imidazole derivatives: Thermally stable organic luminescence materials. Mater Chem Phys 100: 460463.

18. Martinez-Carrera S (1966) The crystal structure of imidazole at $-150^{\circ} \mathrm{C}$. Acta Cryst 35: 783-789.

19. Rashidi AM, Amadeh A (2009) The effect of saccharin addition and bath temperature on the grain size of nanocrystalline nickel coatings. Surf Coat Technol 204: 353-358

20. Gusain D, Srivastava V, Singh VK, Sharma YC (2014) Crystallite size and phase transition demeanor of ceramic steel. Mater Chem Phys 145: 320-326.

21. Waser M (2012) Asymmetric Organocatalysis in Natural Product Syntheses (Progress in the Chemistry of Organic Natural Products). Springer Science \& Business Media, New York, US.

22. Trivedi MK, Patil S, Tallapragada RM (2013) Effect of biofield treatment on the physical and thermal characteristics of silicon, tin and lead powders. J Material Sci Eng S 111-136.

23. Trivedi MK, Nayak G, Patil S, Tallapragada RM, Latiyal O, et al. (2015) The potential impact of biofield treatment on physical, structural and mechanical properties of stainless steel powder. J Appl Mech Eng 4: 1-5.

24. Califano S (1976). Vibrational States. New York: Wiley.
Citation: Trivedi MK, Branton A, Trivedi D, Nayak G, Saikia G, et al. (2015) Physical and Structural Characterization of Biofield Treated Imidazole Derivatives. Nat Prod Chem Res 3: 187. doi:10.4172/2329-6836.1000187
Submit your next manuscript and get advantages of OMICS Group submissions

Unique features:

User friendly/feasible website-translation of your paper to 50 world's leading languages

Audio Version of published paper

Digital articles to share and explore

Special features:

400 Open Access Journals

30,000 editorial tean

21 days rapid review proces

Quality and quick editorial, review and publication processing

- Indexing at PubMed (partial), Scopus, EBSCO, Index Copernicus and Google Scholar etc

- Sharing Option: Social Networking Enabled

- Authors, Reviewers and Editors rewarded with online Scientific Credits

- Better discount for your subsequent articles

Submit your manuscript at: http://www.omicsonline.org/submission/ 